\title{
Release Profiles of Dyes and Proteins from Calcium Phosphate Microspheres with Different Crystalline Phases
}

\author{
Toshiki Miyazaki *(D), Koudai Masuda and Kazuki Sakamoto \\ Graduate School of Life Science and Systems Engineering, Kyushu Institute of Technology, \\ Kitakyushu 808-0196, Japan; masuda.koudai201@mail.kyutech.jp (K.M.); \\ sakamoto.kazuki273@mail.kyutech.jp (K.S.) \\ * Correspondence: tmiya@life.kyutech.ac.jp; Tel./Fax: +81-93-695-6025
}

Citation: Miyazaki, T.; Masuda, K.; Sakamoto, K. Release Profiles of Dyes and Proteins from Calcium Phosphate Microspheres with Different Crystalline Phases. Ceramics 2021, 4, 291-301. https://doi.org/10.3390/ ceramics 4020023

Academic Editor: Gilbert Fantozzi

Received: 28 April 2021

Accepted: 4 June 2021

Published: 6 June 2021

Publisher's Note: MDPI stays neutral with regard to jurisdictional claims in published maps and institutional affiliations.

Copyright: (c) 2021 by the authors. Licensee MDPI, Basel, Switzerland. This article is an open access article distributed under the terms and conditions of the Creative Commons Attribution (CC BY) license (https:// creativecommons.org/licenses/by/ $4.0 /)$.

\begin{abstract}
Calcium phosphate is attracting attention as a bone repair material and a controlled-release carrier of various drugs such as bone disease therapeutic agents and anticancer agents. Compared with some bioabsorbable polymers, calcium phosphates have the advantage of preventing a $\mathrm{pH}$ decrease in the surrounding body fluid. However, there are few studies comparing the effect of supporting substances with different physicochemical properties on the production of calcium phosphate microspheres with different crystalline phases. In this study, we investigated conditions for obtaining low crystallinity apatite and octacalcium phosphate (OCP) microspheres from calcium carbonate microspheres with different crystalline structures using a simple phosphoric acid treatment. Furthermore, we investigated the adsorption and release behavior of different dyes and proteins from the apatite and OCP microspheres. Overall, the factors governing the adsorption and release behavior are different depending on the molecular size and surface charge of the dye and protein adsorbates.
\end{abstract}

Keywords: apatite; octacalcium phosphate (OCP); microsphere; drug delivery; dye; protein; mesopore; surface charge

\section{Introduction}

Calcium phosphate is attracting attention as a bone repair material and a controlledrelease carrier for various drugs such as bone disease therapeutic agents and anticancer agents [1,2]. Carriers must pass through capillaries; as a result, the carrier is preferably smaller than the typical 5- $\mu \mathrm{m}$ diameter of capillaries [3]. In addition, a sphere is a desirable shape to prevent damage to blood vessels. Extensive studies have been conducted on bioabsorbable poly-lactic-co-glycolic acid microspheres for controlled drug release; however, inflammation by their acidic degradation products is a concern [4,5]. To address these concerns, calcium phosphate has been added to suppress the $\mathrm{pH}$ decrease during degradation [6], and the degradation rate of calcium phosphate microspheres has been controlled by additives such as $\mathrm{Sr}^{2+}$ [7]. Various studies using composite microspheres as scaffolds for vascular regeneration in ischemic diseases have been reported [8].

Microspheres of various calcium phosphates, such as apatite [9], tricalcium phosphate (TCP) [10], octacalcium phosphate (OCP) [11], and biphasic calcium phosphate [12,13], have been fabricated, and the crystalline phase of calcium phosphate has been controlled by changing the heating temperature $[14,15]$. The drug and protein release profile have been investigated for some of these studies; however, few adsorbates have been used. There are few comparative studies using a range of supporting substances, from compounds with low molecular weight to proteins, to fabricate calcium phosphate microspheres with different crystalline phases.

In this study, we investigated the conditions for obtaining microspheres consisting of low crystallinity apatite and OCP from calcium carbonate microspheres with different crystalline structures using a simple phosphoric acid treatment. A high drug incorporation is expected because the plate-like morphology of OCP has a high specific surface area and 
a specific layered structure $[16,17]$. Vaterite-type calcium carbonate microspheres with suitable size for drug delivery are commercially available, and they can be easily converted into calcite by a simple heat treatment. We assumed that different calcium phosphates can be obtained in an aqueous process using vaterite and calcite because the precursors have different solubility products and reactivity [18]. Furthermore, the adsorption and release behaviors of dyes with different charges were investigated as models for drugs and proteins with different isoelectric points, and the interaction mechanism between the microspheres and adsorbates was defined.

\section{Materials and Methods}

\subsection{Materials}

Vaterite-type $\mathrm{CaCO}_{3}$ microspheres (SCS-M5, 5- $\mu \mathrm{m}$ particle size, Sakai Chemical Industry Co., Ltd., Sakai, Japan) were used as a starting material. $\mathrm{NaCl}$ and $\mathrm{H}_{3} \mathrm{PO}_{4}$ were purchased from Nacalai Tesque Inc., Kyoto, Japan and XL-Bradford reagent was purchased from Intégrale Co., Ltd., Tokyo, Japan. Methylene blue, eosin Y, albumin derived from egg, $\gamma$-globulin derived from human blood plasma, and lysozyme derived from egg white were purchased from FUJIFILM Wako Pure Chemical Industries Co., Osaka, Japan.

\section{2. $\mathrm{H}_{3} \mathrm{PO}_{4}$ Treatment of $\mathrm{CaCO}_{3}$ Microspheres}

The methods for the preparation of apatite and $\mathrm{OCP}$ by $\mathrm{H}_{3} \mathrm{PO}_{4}$ treatment of $\mathrm{CaCO}_{3}$ were previously reported $[19,20]$. To convert vaterite to calcite, an alumina crucible containing the microspheres was placed in an electric furnace (300-Plus, DENKEN-HIGHDENTAL Co., Ltd., Kyoto, Japan) maintained at $460{ }^{\circ} \mathrm{C}$ and heated for $30 \mathrm{~min}$. The microspheres were then cooled in air. Preliminary thermal analysis demonstrated that the phase transition from vaterite to calcite occurred between $420^{\circ} \mathrm{C}$ and $460{ }^{\circ} \mathrm{C}$. The heating temperature was set to $460^{\circ} \mathrm{C}$ to ensure complete transition. Vaterite microspheres $(1.33 \mathrm{~g})$ were added to a $0.1 \mathrm{M} \mathrm{H}_{3} \mathrm{PO}_{4}$ solution heated to $60^{\circ} \mathrm{C}$. The solution was adjusted to $\mathrm{pH} 6$ with $1 \mathrm{M}$ aqueous solutions of $\mathrm{HNO}_{3}$ and $\mathrm{NaOH}$. The mixture was stirred for $1 \mathrm{~h}$ using a homogenizer (Homogenizing Mixer MARK II Model 2.5, PRIMIX Co., Hyogo, Japan). Alternatively, calcite microspheres $(1.33 \mathrm{~g})$ obtained by heat treatment of the vaterite were added to a $0.1 \mathrm{M}$ $\mathrm{H}_{3} \mathrm{PO}_{4}$ solution heated to $60^{\circ} \mathrm{C}$, and methylene blue was added to achieve $3.2 \times 10^{-3} \mathrm{M}$. The $\mathrm{pH}$ of the solution was adjusted to $\mathrm{pH} 4-7$ with $1 \mathrm{M} \mathrm{HNO}_{3}$ and $\mathrm{NaOH}$ (aqueous) using a pH controller (NPH-680D, Nisshin Rika Co., Ltd., Tokyo, Japan). After stirring, the samples were filtered and washed with ultrapure water, then dried in a $60{ }^{\circ} \mathrm{C}$ oven (NDO-700, EYELA, Tokyo, Japan).

\subsection{Dye Adsorption and Release}

First, $0.1 \mathrm{~g}$ of apatite and OCP microspheres were immersed in $10 \mathrm{~mL}$ of $5.0 \times 10^{-5}$ to $6.4 \times 10^{-3} \mathrm{M}$ aqueous methylene blue solution and $5.0 \times 10^{-4}$ to $1.0 \times 10^{-1} \mathrm{M}$ aqueous eosin $\mathrm{Y}$ solution. The mixture was stored for $4 \mathrm{~h}$. The absorbance in the supernatant was measured using an ultraviolet-visible spectrophotometer (UV-Vis: V-603, JASCO Co., Tokyo, Japan) to determine the saturated adsorption concentration. The measurement wavelength was 664 and $517 \mathrm{~nm}$ for methylene blue and eosin Y, respectively. Microspheres $(0.01 \mathrm{~g})$, after immersion in dye solutions with saturated adsorption concentrations $\left(3.2 \times 10^{-3} \mathrm{M}\right.$ for methylene blue and $5.0 \times 10^{-2} \mathrm{M}$ for eosin $\mathrm{Y}$ ), were transferred to $10 \mathrm{~mL}$ of physiological saline heated to $38^{\circ} \mathrm{C}$. The absorbance of the supernatant was then measured at different times within $24 \mathrm{~h}$ using a UV-Vis spectrophotometer to investigate the release behavior.

\subsection{Protein Adsorption and Release}

Apatite and OCP microspheres with a total surface area of $3 \mathrm{~m}^{2}$ were immersed in $10 \mathrm{~mL}$ of an albumin, $\gamma$-globulin, and lysozyme solution (each protein concentration was 0 to $1.0 \mathrm{~g} / \mathrm{L}$ ), and the solution was stored at $38^{\circ} \mathrm{C}$ for $4 \mathrm{~h}$. Then, $70 \mu \mathrm{L}$ of the supernatant and standard solutions were transferred to polystyrene cells, $3.5 \mathrm{~mL}$ of the XL-Bradford reagent (diluted five times with ultrapure water) was added to each cell, and the solution 
was stored at room temperature for $5 \mathrm{~min}$. The absorbance at $595 \mathrm{~nm}$ was then measured using the UV-Vis spectrophotometer to calculate the amount of adsorption.

Apatite and OCP microspheres with a total surface area of $0.3 \mathrm{~m}^{2}$ were immersed in a solution containing $1.0 \mathrm{~g} / \mathrm{L}$ albumin, $0.6 \mathrm{~g} / \mathrm{L} \gamma$-globulin, and $1.0 \mathrm{~g} / \mathrm{L}$ lysozyme for $4 \mathrm{~h}$. The microspheres were then immersed in $10 \mathrm{~mL}$ of physiological saline and stored at $38^{\circ} \mathrm{C}$. The released protein concentration was measured at different times within $24 \mathrm{~h}$ by the method described above.

\subsection{Structural Analysis}

The surface morphology of the samples was observed with a scanning electron microscope (SEM: S-3500N, Hitachi, Ltd., Tokyo, Japan). The samples were coated with an Au-Pd alloy using an ion sputtering device (E-101, Hitachi, Ltd., Tokyo, Japan). Powder X-ray diffraction (XRD: M03XHF 22 , Mac Science Co., Ltd., Yokohama, Japan) was performed with a $\mathrm{CuK} \alpha \mathrm{X}$-ray as a source, and the crystalline structure of the samples was identified by referring to the Joint Committee on Powder Diffraction Standards (JCPDS) data file. The voltage and current applied to the X-ray tube were $40 \mathrm{kV}$ and $30 \mathrm{~mA}$, respectively. The step-scanning mode with a step width of $0.02^{\circ}$ and counting time of $2 \mathrm{~s}$ were used.

The adsorption isotherm of the samples was measured using an automatic specific surface area/pore distribution measuring device (BELSORP-mini II, Nippon Bell Co., Ltd., Osaka, Japan). As a pre-treatment, the microspheres were evacuated at room temperature for $6 \mathrm{~h}$. The measurement was performed with an equilibrium time of $180 \mathrm{~s}$, and $\mathrm{N}_{2}$ gas was adsorbed at $-196{ }^{\circ} \mathrm{C}$. The specific surface area was calculated using the BrunauerEmmett-Teller (BET) theory. The pore distribution was determined from the desorption isotherm by the Barrett-Joyner-Halenda (BJH) method.

The surface zeta potentials of the samples were measured in a $10-\mathrm{mM} \mathrm{NaCl}$ aqueous solution with a zeta potential analyzer (ELS-Z, Otsuka Electronics Co., Ltd., Osaka, Japan). A quartz cell was used for the measurement.

\section{Results}

The crystalline phase after heat treatment of the vaterite microspheres was identified as a single phase of calcite by XRD. Figure 1 shows the XRD pattern and SEM photograph of the microspheres obtained by $\mathrm{H}_{3} \mathrm{PO}_{4}$ treatment of the vaterite microspheres. Spherical particles with a diameter of 5 to $10 \mu \mathrm{m}$ were obtained. The crystalline phase was identified as low crystallinity apatite. Figure 2 shows the XRD patterns and SEM photographs of the microspheres obtained by $\mathrm{H}_{3} \mathrm{PO}_{4}$ treatment of the calcite microspheres at various $\mathrm{pH}$ values. The crystalline phase was $\mathrm{CaHPO}_{4} \cdot \mathrm{H}_{2} \mathrm{O}$ with a small amount of OCP at $\mathrm{pH}$. OCP with a small amount of apatite was detected at pH 5 to 6 . The peak intensity near $4.7^{\circ}$ assigned to the (010) diffraction of OCP was the highest at $\mathrm{pH} 5.5$. The crystalline phase was only apatite at $\mathrm{pH} 7$. Hereafter, the apatite microspheres shown in Figure 1 and OCP microspheres obtained at $\mathrm{pH} 5.5$, as shown in Figure 2, were used.

Figure 3 shows the FT-IR spectra of the apatite and OCP microspheres and calcite microspheres. Only peaks assigned to carbonate ions were observed at 700, 900, and $1400 \mathrm{~cm}^{-1}$ for the calcite microspheres. Alternatively, peaks assigned to the $\mathrm{P}-\mathrm{O}$ bond were observed at 600 and $1000 \mathrm{~cm}^{-1}$ for the apatite and OCP microspheres, respectively; those assigned to carbonate completely disappeared. 

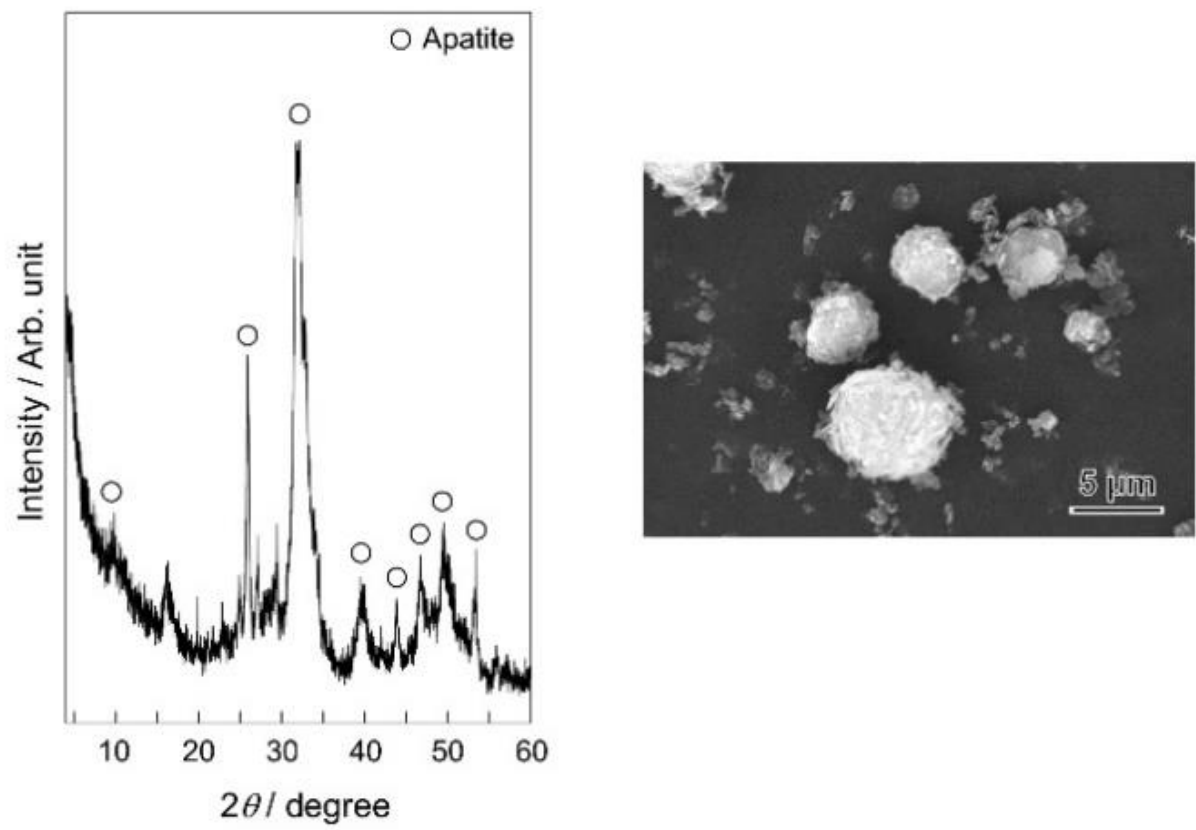

Figure 1. X-ray diffraction pattern and scanning electron microscope photograph of the microspheres obtained by $\mathrm{H}_{3} \mathrm{PO}_{4}$ treatment of the vaterite microspheres.
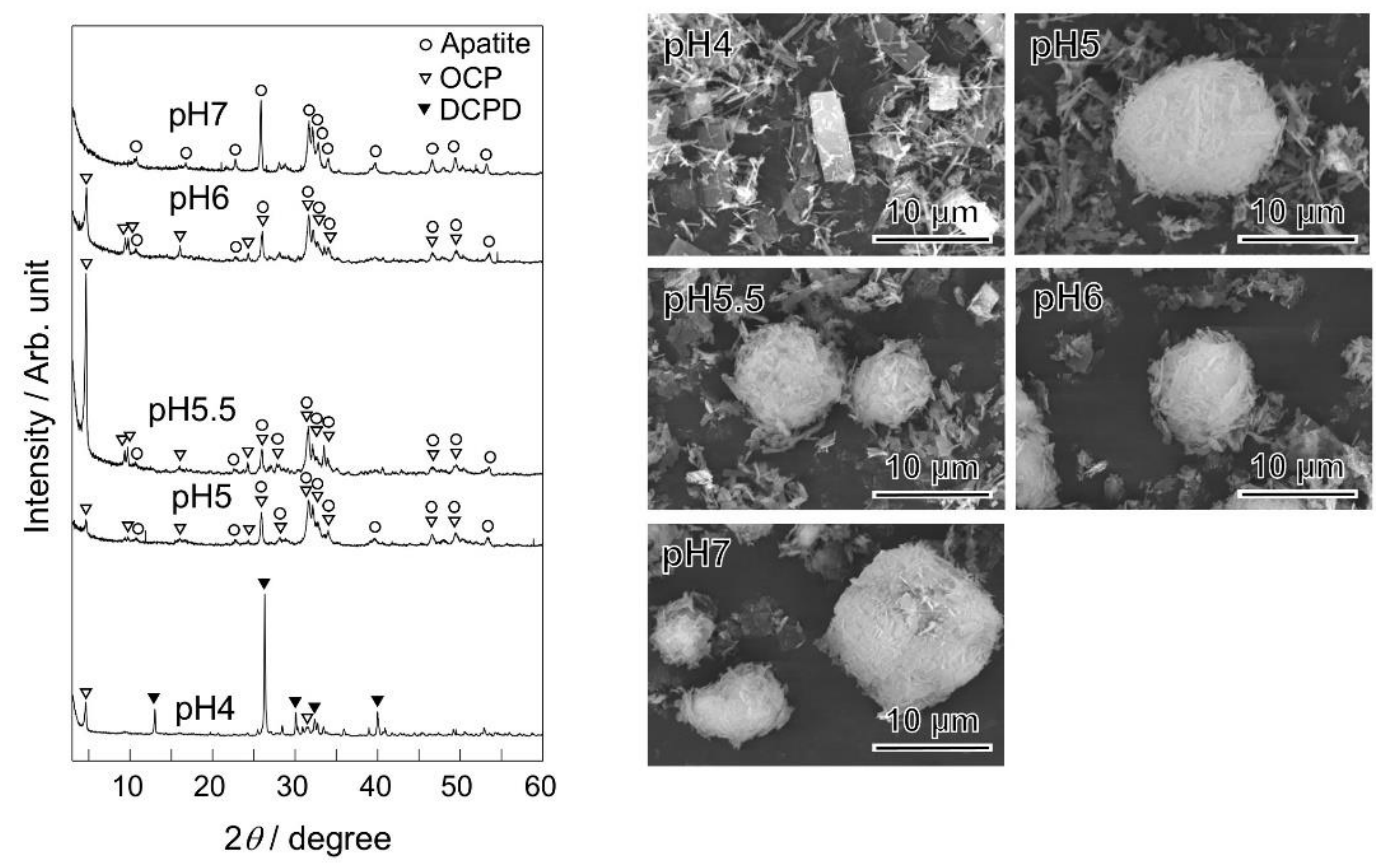

Figure 2. X-ray diffraction patterns and scanning electron microscope photographs of the microspheres obtained by $\mathrm{H}_{3} \mathrm{PO}_{4}$ treatment of the calcite microspheres at various $\mathrm{pH}$ values. 


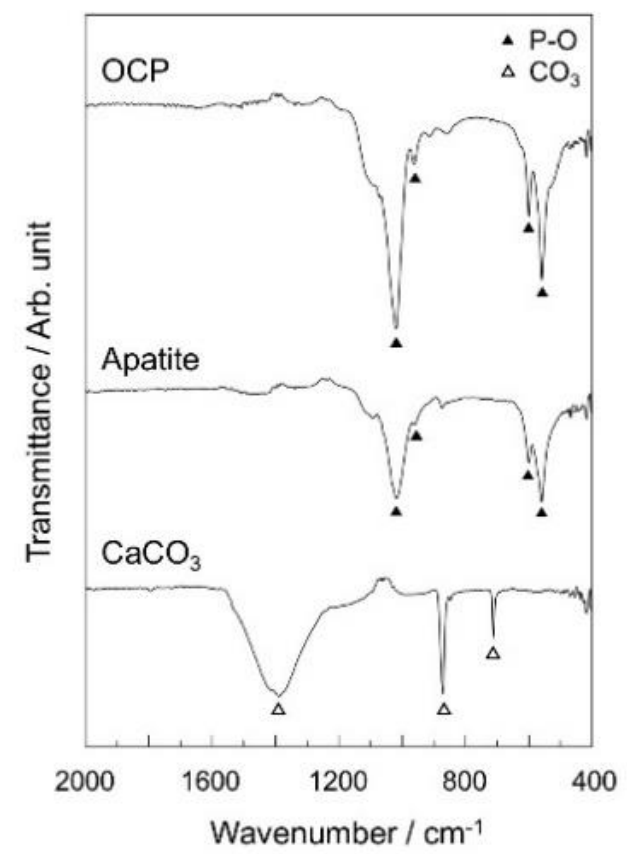

Figure 3. FT-IR spectra of the OCP, apatite, and calcite microspheres.

Figure 4 shows the adsorption isotherm of the apatite and OCP microspheres. In the case of apatite, the shape of the isotherm was categorized as Type IV according to the International Union of Pure and Applied Chemistry (IUPAC) classification, suggesting the existence of 2 to $50 \mathrm{~nm}$ mesopores. Hysteresis was observed at a relative pressure of 0.5 to 1.0, also suggesting the existence of mesopores. The shape of the hysteresis was categorized as a combination of Type $\mathrm{H} 3$ and $\mathrm{H} 4$ of the IUPAC classification. Type H3 indicates the presence of slit-type pores and aggregates of plate-like particles, and Type $\mathrm{H} 4$ indicates the presence of micropores smaller than $2 \mathrm{~nm}$.
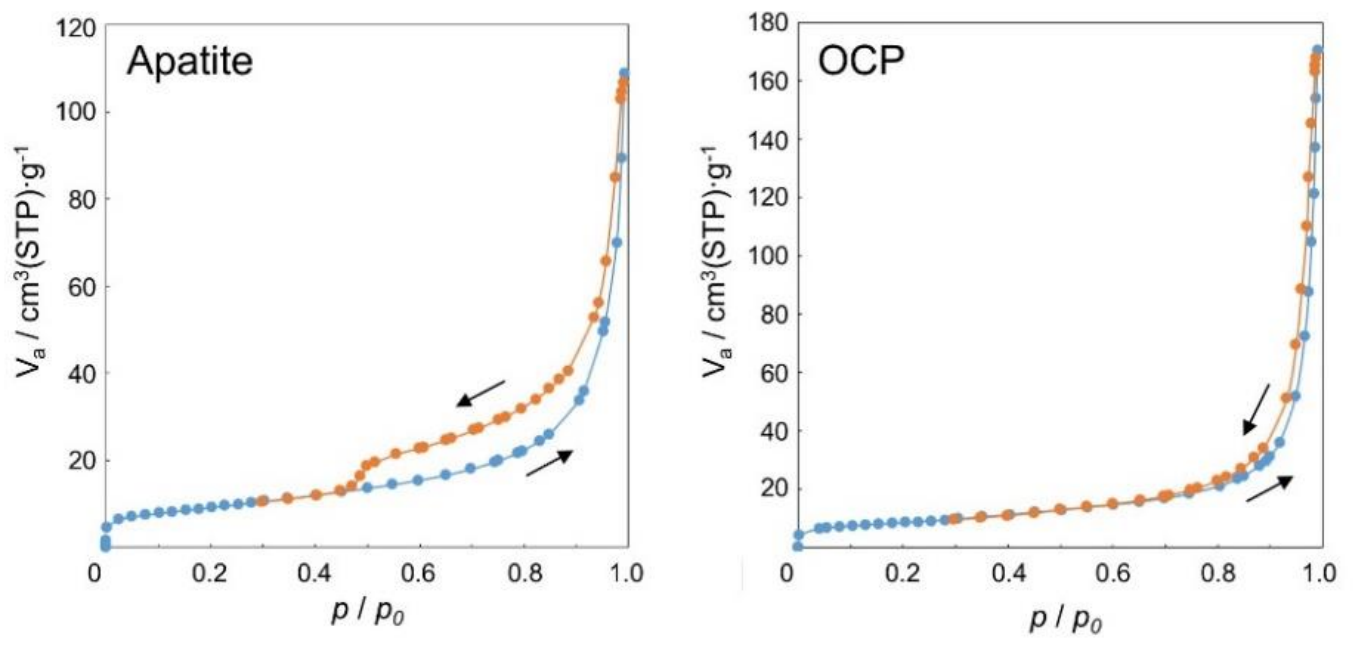

Figure 4. Adsorption isotherm of the apatite and OCP microspheres.

In the case of OCP, the shape of the isotherm was categorized as a combination of Type II and Type IV. Type II indicates that there were no pores or only macropores larger than $50 \mathrm{~nm}$. Because the adsorption amount increased at a relative pressure of 0.9 or greater, there is the possibility of the presence of macropores or aggregates of the small particles. Hysteresis was observed at a relative pressure of 0.8 to 1.0, suggesting the existence of 
mesopores. The hysteresis pattern indicates Type H3. The specific surface area of apatite and OCP was 32.8 and $30.0 \mathrm{~m}^{2} / \mathrm{g}$, respectively, according to BET theory.

Figure 5 shows the $\mathrm{BJH}$ pore size distribution of the apatite and OCP microspheres. The average diameter of the pores in apatite was $20.0 \mathrm{~nm}$. Distributions showing peaks near diameters of 2.5 and $7 \mathrm{~nm}$ were attributed to the mesopores. A broad increase in $\mathrm{d} V_{p} / \mathrm{d} d_{p}$ was observed below $2 \mathrm{~nm}$, suggesting the existence of micropores. Alternatively, the average diameter of the pores in OCP was $36.2 \mathrm{~nm}$. Distributions showing peaks near 3 and $35 \mathrm{~nm}$ in diameter were attributed to the mesopores. In addition, a broad increase in $\mathrm{d} V_{p} / \mathrm{d} d_{p}$ was observed at $2 \mathrm{~nm}$, similar to apatite. However, the non-spherical particles observed in Figures 1 and 2 may also affect the pore size distribution at the micrometer or submicron level.
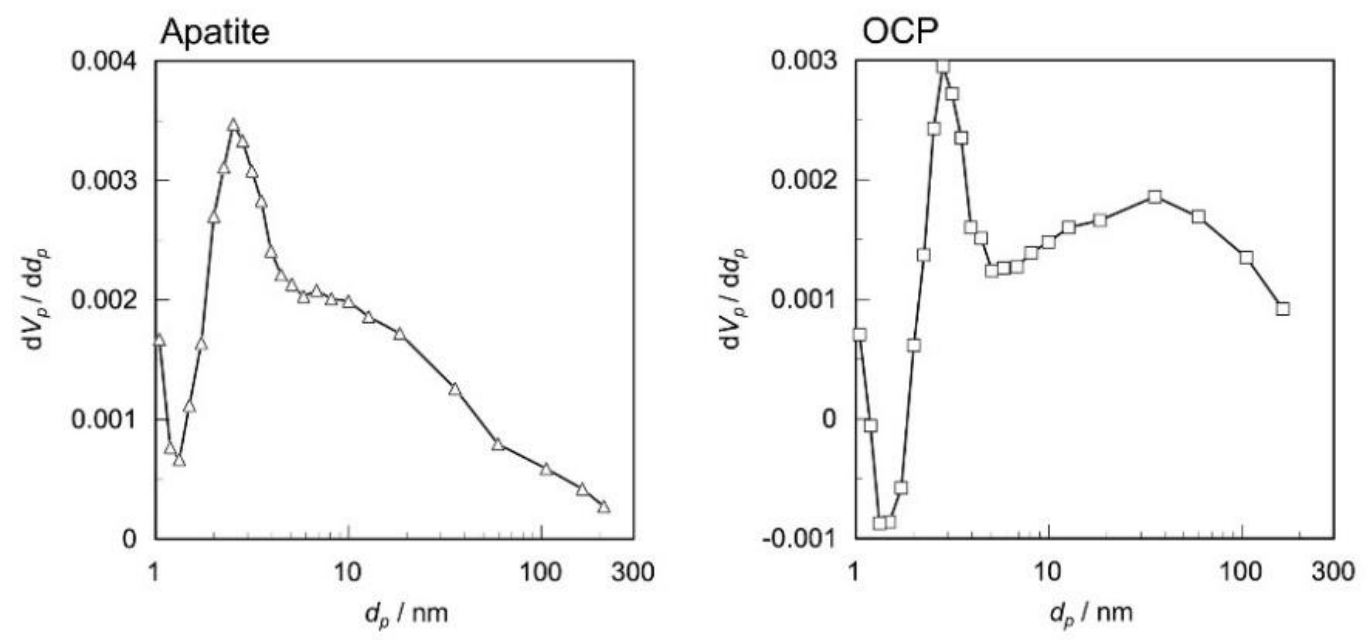

Figure 5. BJH pore size distribution of apatite and OCP microspheres.

Figure 6 shows the appearance of OCP microspheres after immersion in the methylene blue solution and microspheres prepared with the addition of methylene blue. The microspheres prepared with methylene blue showed a darker blue color.
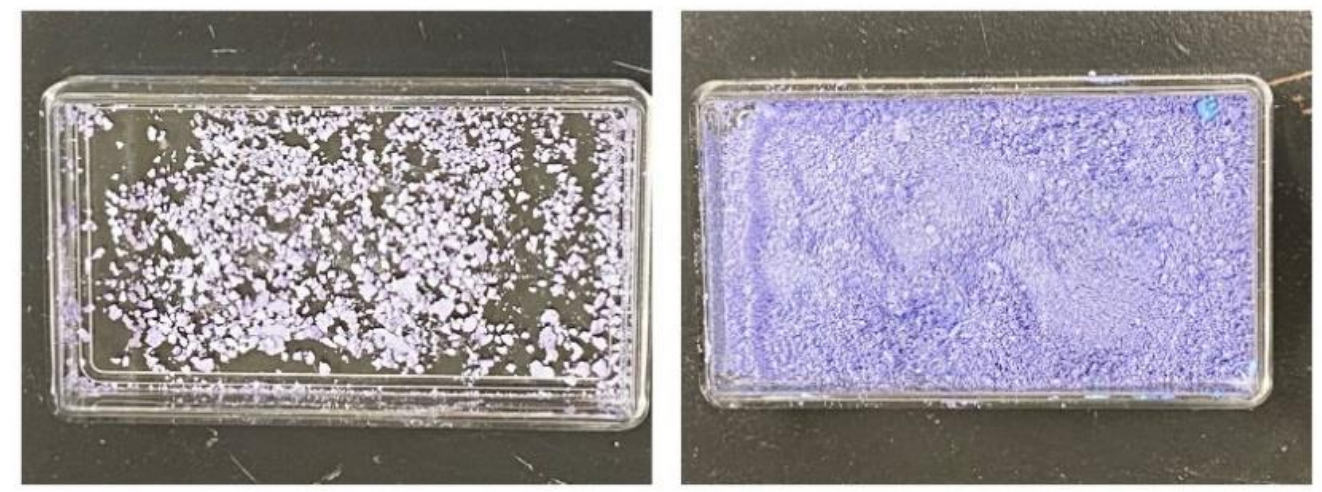

Figure 6. Appearance of OCP microspheres after immersion in the methylene blue solution (Left) and microspheres prepared with the addition of methylene blue (Right).

Figure 7 shows the adsorption and release profiles of various dyes and proteins incorporated into the apatite and OCP microspheres by post-treatment. The amount of methylene blue adsorbed to the apatite was greater than absorbed to $\mathrm{OCP}$, and vice versa for eosin $\mathrm{Y}$. In addition, OCP showed a higher release rate than apatite. The release rate of eosin $\mathrm{Y}$ in $\mathrm{OCP}$ was much greater than that in methylene blue. In the case of protein, the adsorption amount was greater in $\mathrm{OCP}$, and the release rate was greater in apatite. In the case of lysozyme, the difference between the apatite and OCP was relatively small. 
Methylene blue
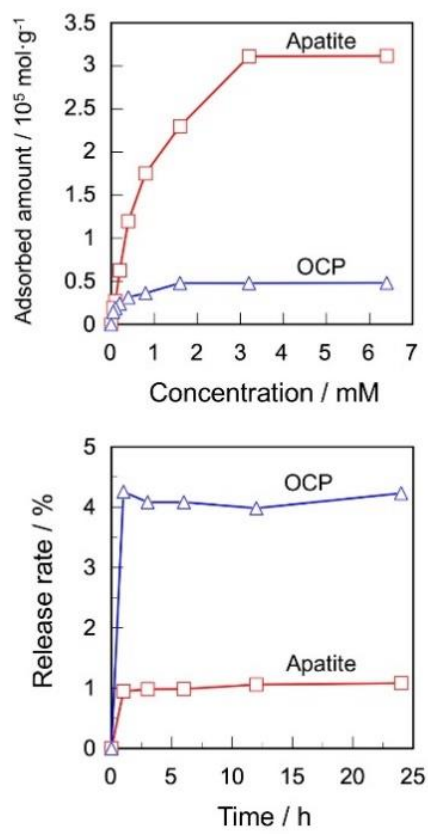

Albumin
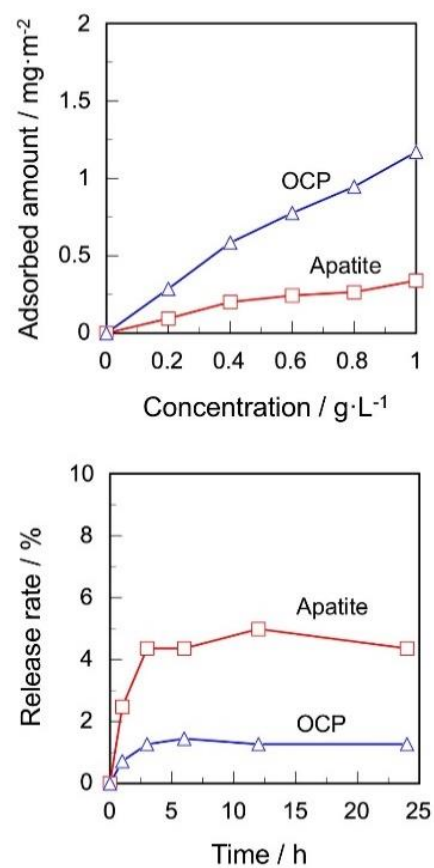

Eosin $Y$
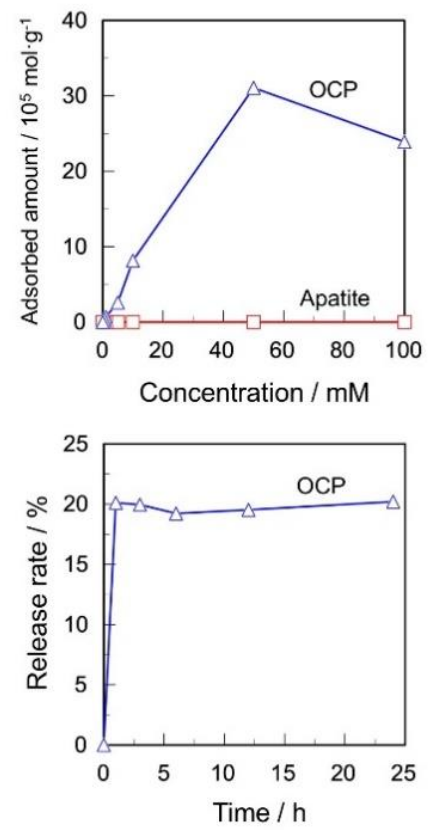

$\gamma$-Globulin
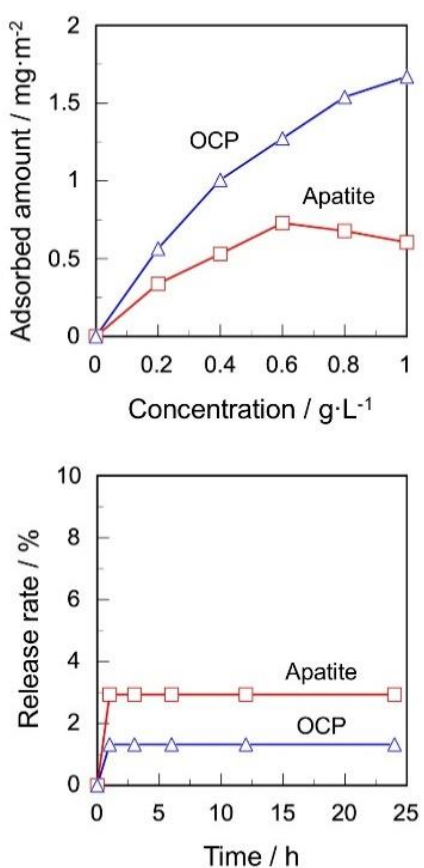

Lysozyme
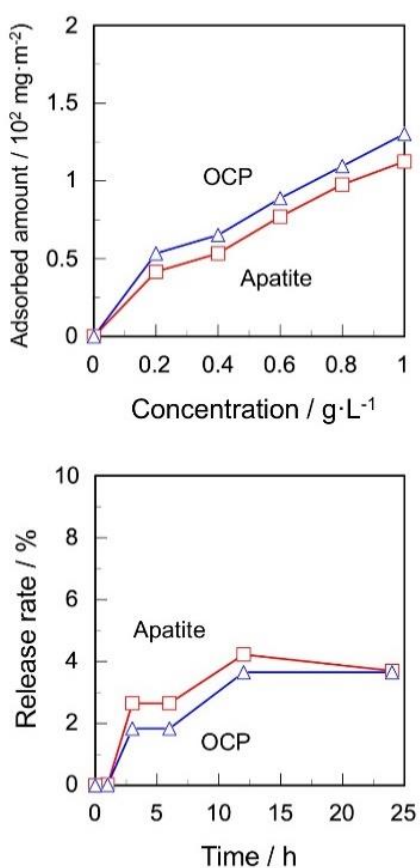

Figure 7. Adsorption and release profiles of various dyes and proteins incorporated into apatite and OCP microspheres by post treatment. The release rate of eosin $\mathrm{Y}$ from the apatite was not measured because the adsorbed amount was too small.

The zeta potential of apatite and OCP was $-30.9 \pm 0.6$ and $-20.5 \pm 1.1 \mathrm{mV}$, respectively.

\section{Discussion}

In the synthesis of calcium phosphate microspheres by $\mathrm{H}_{3} \mathrm{PO}_{4}$ treatment of $\mathrm{CaCO}_{3}$ microspheres, the crystalline phase of the calcium phosphate depends on the starting material (Figures 1 and 2). Specifically, low crystallinity apatite was formed at pH 6 in 
vaterite, while OCP was the primary crystalline phase, even at $\mathrm{pH} 6$ in the calcite. Vaterite has greater solubility than calcite [18]. Therefore, an increase in local $\mathrm{Ca}^{2+}$ concentration by rapid dissolution of vaterite results in the formation of apatite with less solubility than OCP. In addition, the stable $\mathrm{pH}$ of OCP is 4.7 to 5.8 at $60{ }^{\circ} \mathrm{C}$, and $\mathrm{CaHPO}_{4} \cdot \mathrm{H}_{2} \mathrm{O}$ and apatite are stable at lower and higher $\mathrm{pH}$, respectively [21]. These findings coincide with the results of this study.

Apatite was synthesized from $\mathrm{CaCO}_{3}$ as a starting material; however, the product contained nearly no carbonate ions (Figure 3). Apatite with 2.64 mass $\%$ carbonate is typically precipitated from a simulated body fluid with inorganic ion concentrations nearly equal to that of human plasma at $\mathrm{pH} 7.25$ [22]. In a carbonate solution of approximately $\mathrm{pH} 6$ (synthetic condition for apatite), 75\% of the carbonate is reported to be present as $\mathrm{CO}_{2}$ and $25 \%$ is $\mathrm{HCO}_{3}{ }^{-}$[23]. Furthermore, the equilibrium moves to the right in the chemical reaction of Equation (1) if $\mathrm{CO}_{2}$ gas evaporates. Therefore, the amount of $\mathrm{HCO}_{3}{ }^{-}$decreases and it is not incorporated into the apatite crystals.

$$
\mathrm{H}^{+}+\mathrm{HCO}_{3}^{-} \rightleftarrows \mathrm{H}_{2} \mathrm{O}+\mathrm{CO}_{2} \uparrow
$$

Gas formation was actually observed during the reaction of $\mathrm{CaCO}_{3}$ with $\mathrm{H}_{3} \mathrm{PO}_{4}$, which is similar to previous studies $[20,24]$.

The amount of methylene blue adsorbed to the apatite was greater than that adsorbed to OCP, while the release rate of methylene blue from OCP was greater than that from apatite (Figure 6). The size of methylene blue and interlayer distance of OCP are $1.70 \times 0.76 \times 0.33 \mathrm{~nm}$ [25] and $1.87 \mathrm{~nm}$ [26], respectively. Therefore, the relatively small methylene blue molecules can be preferentially incorporated into the interlayer of OCP. However, the result was the opposite of the expectation. Because the apatite is more negatively charged than OCP, OCP has greater electrostatic interaction with the positively charged methylene blue. Therefore, the electrostatic interaction is a more dominant factor than the pore structure regarding the methylene blue release when it is incorporated into OCP by post treatment.

Monma showed that if OCP was synthesized in the presence of various negatively charged dicarboxylic acids, the acids were incorporated into the interlayer of OCP and the distance increased to approximately $2.6 \mathrm{~nm}$ depending on the molecular size of the acid [27]. In the present study, a large amount of methylene blue was incorporated during OCP synthesis (Figure 6), which was expected to promote the release of methylene blue.

Alternatively, OCP adsorbed more eosin $\mathrm{Y}$ than apatite, while its release rate was also greater than methylene blue (Figure 7). Considering the electrostatic interaction, it is difficult for negatively charged eosin $\mathrm{Y}$ to adsorb to both apatite and OCP. Although the molecular size of the eosin $Y$ has not been reported, methylene blue $(\mathrm{Mw}=319.9)$ has a chemical structure with three benzene rings, while eosin $Y(M w=691.9)$ has a fourth benzene ring in the side chain, indicating a larger molecular size than methylene blue. Therefore, eosin $\mathrm{Y}$ is likely adsorbed on the mesopores of OCP (Figures 4 and 5). As a result, the release of eosin $\mathrm{Y}$ is enhanced because of its weak electrostatic interaction with OCP.

OCP showed greater adsorption of all proteins than apatite (Figure 7). The long side of albumin, $\gamma$-globulin, and lysozyme are $14 \mathrm{~nm}$ [28], 10-20 nm [29], and $9 \mathrm{~nm}$ [30], respectively. Because these proteins are difficult to incorporate into the interlayer of OCP, the mesopores in OCP markedly contributed to the adsorption (Figures 4 and 5). The difference in lysozyme adsorption between apatite and OCP was less than that of albumin and $\gamma$-globulin. The isoelectric points of albumin, $\gamma$-globulin, and lysozyme are 4.8 [31], 5.2 to 9.2 [32], and 11 [33], respectively; as a result, lysozyme is highly positively charged in neutral conditions. Therefore, the electrostatic interactions between the amino group on the lysozyme and the phosphate group on the microsphere surface are strong in both the apatite and OCP.

Alternatively, the release rate of all proteins from apatite was greater than from OCP (Figure 7). Apatite can easily release proteins because it contains no mesopores larger than the protein molecules. Kanno et al. investigated the release behavior of albumin and 
lysozyme from carbonate apatite particles [34]. In their study, the carbonate content was $1.1 \mathrm{mass} \%$ and the release rate of lysozyme was greater than that of albumin, which is consistent with the results of this study. However, the release rate was $60 \%$ or greater for the Kanno et al. study, which is considerably greater than our study, likely because of the high specific surface area $\left(75 \mathrm{~m}^{2} / \mathrm{g}\right)$ and use of a dynamic fluid system for the protein release.

Suzuki et al. reported that OCP has better albumin adsorption capacity than apatite obtained by hydrolysis of OCP [35], which is consistent with this study. The results of Suzuki et al. also suggest that the adsorption characteristics gradually change in the biological environment. However, there are no studies comparing the hydrolysis rate of OCP in the presence of proteins. Alternatively, the hydrolysis rate of $\alpha$-TCP to OCP decreases in the presence of polyacrylic acid [36]. Therefore, the adsorbed protein might stabilize the OCP phase in the biological environment. This point should be clarified in future studies.

All of the calcium phosphates used in this study were negatively charged. Although protein adsorption on negatively charged apatite and positively charged alumina was previously compared in aqueous solutions containing bovine serum [37], there is no comparative study concerning the protein adsorption on calcium phosphates that are positively and negatively charged. Aizawa et al. found that some of the c-axis oriented fibrous apatite is positively charged [38], suggesting the potential to study protein adsorption on positively and negatively charged calcium phosphates.

The protein release rate from the microspheres in this study was less than $6 \%$ for all conditions, suggesting chemical adsorption of the proteins (Figure 7). Particle size has a great influence on the protein release behavior from apatite. Wen et al. fabricated a thin film comprising apatite and OCP with a thickness of $0.3 \mu \mathrm{m}$ and length of $5 \mu \mathrm{m}$ on titanium substrates [39]. The albumin adsorbed on the film had limited release at $\mathrm{pH}$ 7.4; however, $30 \%$ or more was released at $\mathrm{pH} 4.0$. The release rate of cytochrome $\mathrm{c}$ from rod-shaped apatite with a length of $200 \mathrm{~nm}$ to $2 \mu \mathrm{m}$ was also $20 \%$ or less [40]. Alternatively, the release rate of albumin from the rod-shaped apatite with a length of 40 to $100 \mathrm{~nm}$ was $90 \%$ or more, even at $\mathrm{pH} 7.2$ [41]. Furthermore, the protein release behavior from polymer fibers is controlled by hydrophilicity [42]. Future works should investigate the important factors of particle size and surface wettability to promote protein release.

\section{Conclusions}

Apatite microspheres were prepared by $\mathrm{H}_{3} \mathrm{PO}_{4}$ treatment of vaterite at $\mathrm{pH}$ 6, and $\mathrm{OCP}$ microspheres were prepared by $\mathrm{H}_{3} \mathrm{PO}_{4}$ treatment of calcite at $\mathrm{pH} 5$ to 6 . A comparison of the adsorption and release of various dyes and proteins from the microspheres suggested that electrostatic interactions were dominant for methylene blue and the pore structure was dominant for eosin $\mathrm{Y}$ and proteins. These results are expected to provide a guideline for obtaining sustained drug release properties from calcium phosphate microspheres.

Author Contributions: Conceptualization, T.M.; methodology, K.M. and K.S.; investigation, K.M. and K.S.; resources, T.M.; data curation, K.M.; writing-original draft preparation, T.M.; writingreview and editing, T.M.; visualization, T.M.; supervision, T.M.; project administration, T.M. All authors have read and agreed to the published version of the manuscript.

Funding: This research received no external funding.

Institutional Review Board Statement: Not applicable.

Informed Consent Statement: Not applicable.

Data Availability Statement: Data is contained within the article.

Acknowledgments: We thank Ashleigh Cooper, from Edanz (https:/ /jp.edanz.com/ac, accessed on 6 June 2021) for editing a draft of this manuscript.

Conflicts of Interest: The authors declare no conflict of interest. 


\section{References}

1. Parent, M.; Baradari, H.; Champion, E.; Damia, C.; Viana-Trecant, M. Design of calcium phosphate ceramics for drug delivery applications in bone diseases: A review of the parameters affecting the loading and release of the therapeutic substance. J. Control. Release 2017, 252, 1-17. [CrossRef] [PubMed]

2. Mondal, S.; Dorozhkin, S.V.; Pal, U. Recent progress on fabrication and drug delivery applications of nanostructured hydroxyapatite. WIREs Nanomed. Nanobiotechnol. 2018, 10, e1504. [CrossRef]

3. Wiedeman, M.P. Dimensions of blood vessels from distributing artery to collecting vein. Circ. Res. 1963, 12, 375-378. [CrossRef] [PubMed]

4. Yang, Y.Y.; Chia, H.H.; Chung, T.S. Effect of preparation temperature on the characteristics and release profiles of PLGA microspheres containing protein fabricated by double-emulsion solvent extraction/evaporation method. J. Control. Release 2000, 69, 81-96. [CrossRef]

5. Lu, L.; Stamatas, G.N.; Mikos, A.G. Controlled release of transforming growth factor $\beta 1$ from biodegradable polymer microparticles. J. Biomed. Mater. Res. 2000, 50, 440-451. [CrossRef]

6. Ho, M.L.; Fu, Y.C.; Wang, G.W.; Chen, H.T.; Chang, J.K.; Tsai, T.H.; Wang, C.K. Controlled release carrier of BSA made by W/O/W emulsion method containing PLGA and hydroxyapatite. J. Control. Release 2008, 128, 142-148. [CrossRef] [PubMed]

7. Chen, Y.; Liu, Z.; Jiang, T.; Zou, X.; Lei, L.; Yan, W.; Yang, J.; Li, B. Strontium-substituted biphasic calcium phosphate microspheres promoted degradation performance and enhanced bone regeneration. J. Biomed. Mater. Res. A 2020, 108, 895-905. [CrossRef]

8. Mima, Y.; Fukumoto, S.; Koyama, H.; Okada, M.; Tanaka, S.; Shoji, T.; Emoto, M.; Furuzono, T.; Nishizawa, Y.; Inaba, M. Enhancement of cell-based therapeutic angiogenesis using a novel type of injectable scaffolds of hydroxyapatite-polymer nanocomposite microspheres. PLoS ONE 2012, 7, e35199. [CrossRef]

9. Sambudi, N.S.; Cho, S.; Cho, K. Porous hollow hydroxyapatite microspheres synthesized by spray pyrolysis using a microalga template: Preparation, drug delivery, and bioactivity. RSC Adv. 2016, 6, 43041-43048. [CrossRef]

10. Chou, J.; Valenzuela, S.; Green, D.W.; Kohan, L.; Milthorpe, B.; Otsuka, M.; Ben-Nissan, B. Antibiotic delivery potential of nanoand micro-porous marine structure-derived $\beta$-tricalcium phosphate spheres for medical applications. Nanomedicine 2014, 9 , 1131-1139. [CrossRef]

11. Tripathi, G.; Miyazaki, T. Synthesis and in vitro biodegradation of pure octacalcium phosphate spheres. Int. J. Appl. Ceram. Tech. 2020, 17, 372-379. [CrossRef]

12. Kamitakahara, M.; Ishii, A.; Matsubara, H.; Kawashita, M.; Furuya, M.; Kanetaka, H. Fabrication and evaluation of ascorbic acid phosphate-loaded spherical porous hydroxyapatite/octacalcium phosphate granules. J. Ceram. Soc. Jpn. 2021, 129, 60-65. [CrossRef]

13. Victor, S.P.; Kumar, T.S.S. BCP ceramic microspheres as drug delivery carriers: Synthesis, characterisation and doxycycline release. J. Mater. Sci.: Mater. Med. 2008, 19, 283-290. [CrossRef] [PubMed]

14. Veljović, D.; Palcevskis, E.; Dindune, A.; Putić, S.; Balać, I.; Petrović, R.; Janaćković, D. Microwave sintering improves the mechanical properties of biphasic calcium phosphates from hydroxyapatite microspheres produced from hydrothermal processing. J. Mater. Sci. 2010, 45, 3175-3183. [CrossRef]

15. Ding, G.-J.; Zhu, Y.-J.; Qi, C.; Lu, B.-Q.; Wu, J.; Chen, F. Porous microspheres of amorphous calcium phosphate: Block copolymer templated microwave-assisted hydrothermal synthesis and application in drug delivery. J. Colloid Interface Sci. 2015, 443, 72-79. [CrossRef]

16. Kokubo, T.; Ito, S.; Huang, Z.T.; Hayashi, T.; Sakka, S.; Kitsugi, T.; Yamamuro, T. Ca, P-rich layer formed on high-strength bioactive glass-ceramic A-W. J. Biomed. Mater. Res. 1990, 24, 331-343. [CrossRef]

17. Ban, S.; Maruno, S. Morphology and microstructure of electrochemically deposited calcium phosphates in a modified simulated body fluid. Biomaterials 1998, 19, 1245-1253. [CrossRef]

18. Trushina, D.B.; Bukreeva, T.V.; Kovalchuk, M.V.; Antipina, M.N. $\mathrm{CaCO}_{3}$ vaterite microparticles for biomedical and personal care applications. Mater. Sci. Eng. C 2014, 45, 644-658. [CrossRef]

19. Kamitakahara, M.; Ohtsuki, C.; Takahashi, A.; Tanihara, M. Effect of silane-coupling treatment on thermal decomposition of octacalcium phosphate. J. Soc. Mater. Sci. Jpn. 2006, 55, 881-884. [CrossRef]

20. Minh, D.P.; Rio, S.; Sharrock, P.; Sebei, H.; Lyczko, N.; Tran, N.D.; Raii, M.; Nzihou, A. Hydroxyapatite starting from calcium carbonate and orthophosphoric acid: Synthesis, characterization, and applications. J. Mater. Sci. 2014, 49, 4261-4269. [CrossRef]

21. Monma, H. Octacalcium phosphate. Gypsum Lime 1980, 1980, 113-121. (In Japanese)

22. Kim, H.M.; Kishimoto, K.; Miyaji, F.; Kokubo, T.; Yao, T.; Suetsugu, Y.; Tanaka, J.; Nakamura, T. Composition and structure of the apatite formed on PET substrates in SBF modified with various ionic activity products. J. Biomed. Mater. Res. 1999, 46, 228-235. [CrossRef]

23. Pismenskaya, N.; Laktionov, E.; Nikonenko, V.; Attar, A.E.; Auclair, B.; Pourcelly, G. Dependence of composition of anionexchange membranes and their electrical conductivity on concentration of sodium salts of carbonic and phosphoric acids. $J$. Membr. Sci. 2001, 181, 185-197. [CrossRef]

24. Bournonville, B.; Nzihou, A.; Sharrock, P.; Depelsenaire, G. Stabilization of minerals by reaction with phosphoric acid: Evolution of model compounds. Process Saf. Environ. Prot. 2006, 84, 117-124. [CrossRef] 
25. Arias, M.; López, E.; Nuñez, A.; Rubinos, D.; Soto, B.; Barral, M.T.; Díaz-Fierros, F. Adsorption of methylene blue by red mud, an oxide-rich byproduct of bauxite refining. In Effect of Mineral-Organic-Microorganism Interactions on Soil and Freshwater Environments; Berthelin, J., Huang, P.M., Bollag, J.M., Andreux, F., Eds.; Springer: Berlin, Germany, 1999; pp. 361-365.

26. Aoki, S.; Sakamoto, K.; Yamaguchi, S.; Nakahira, A. Syntheses of octacalcium phosphate containing dicarboxylic acids and effects of the side groups on the crystal growth of octacalcium phosphate. J. Ceram. Soc. Jpn. 2000, 108, 909-914. [CrossRef]

27. Monma, H. The incorporation of dicarboxylates into octacalcium bis(hydrogenphosphate) tetrakis(phosphate) pentahydrate. Bull. Chem. Soc. Jpn. 1984, 57, 599-600. [CrossRef]

28. Comper, W.D.; Glasgow, E.F. Charge selectivity in kidney ultrafiltration. Kidney Int. 1995, 47, 1242-1251. [CrossRef]

29. Gibizova, V.V.; Sergeeva, I.A.; Petrova, G.P.; Priezzhev, A.V.; Khlebtsov, N.G. Interaction of albumin and $\gamma$-globulin molecules with gold nanoparticles in water solutions. Mosc. Univ. Phys. Bull. 2011, 66, 449-452. [CrossRef]

30. Colvin, J.R. The size and shape of lysozyme. Can. J. Chem. 1952, 30, 831-834. [CrossRef]

31. Peters, T. Serum albumin. Adv. Protein Chem. 1985, 37, 161-245.

32. Da Vela, S.; Roosen-Runge, F.; Skoda, M.W.A.; Jacobs, R.M.J.; Seydel, T.; Frielinghaus, H.; Sztucki, M.; Schweins, R.; Zhang, F.; Schreiber, F. Effective interactions and colloidal stability of bovine $\gamma$-globulin in solution. J. Phys. Chem. B 2017, 121, 5759-5769. [CrossRef]

33. Proctor, V.A.; Cunningham, F.E. The chemistry of lysozyme and its use as a food preservative and a pharmaceutical. CRC Crit. Rev. Food Sci. Nutr. 1988, 26, 359-395. [CrossRef]

34. Kanno, T.; Inaba, M.; Sendai, T.; Horiuchi, J. Protein release properties on carbonate ion-containing apatite in a flow system. J. Ceram. Soc. Jpn. 2013, 121, 393-396. [CrossRef]

35. Suzuki, O.; Yagishita, H.; Yamazaki, M.; Aoba, T. Adsorption of bovine serum albumin onto octacalcium phosphate and its hydrolyzates. Cells Mater. 1995, 5, 45-54.

36. Bigi, A.; Boanini, E.; Botter, R.; Panzavolta, S.; Rubini, K. Alpha-tricalcium phosphate hydrolysis to octacalcium phosphate: Effect of sodium polyacrylate. Biomaterials 2002, 23, 1849-1854. [CrossRef]

37. Kawashita, M.; Hayashi, J.; Kudo, T.; Kanetaka, H.; Li, Z.; Miyazaki, T.; Hashimoto, M. MC3T3-E1 and RAW264.7 cell response to hydroxyapatite and alpha-type alumina adsorbed with bovine serum albumin. J. Biomed. Mater. Res. A 2014, 102, 1880-1886. [CrossRef] [PubMed]

38. Zhuang, Z.; Fujimi, T.J.; Nakamura, M.; Konishi, T.; Yoshimura, H.; Aizawa, M. Development of a,b-plane-oriented hydroxyapatite ceramics as models for living bones and their cell adhesion behavior. Acta Biomater. 2013, 9, 6732-6740. [CrossRef] [PubMed]

39. Wen, H.B.; de Wijn, J.R.; van Blitterswijk, C.A.; de Groot, K. Incorporation of bovine serum albumin in calcium phosphate coating on titanium. J. Biomed. Mater. Res. 1999, 46, 245-252. [CrossRef]

40. Matsumoto, T.; Okazaki, M.; Inoue, M.; Yamaguchi, S.; Kusunose, T.; Toyonaga, T.; Hamada, Y.; Takahashi, J. Hydroxyapatite particles as a controlled release carrier of protein. Biomaterials 2004, 25, 3807-3812. [CrossRef]

41. Dasgupta, S.; Banerjee, S.S.; Bandyopadhyay, A.; Bose, S. Zn- and Mg-doped hydroxyapatite nanoparticles for controlled release of protein. Langmuir 2010, 26, 4958-4964. [CrossRef] [PubMed]

42. Maretschek, S.; Greiner, A.; Kissel, T. Electrospun biodegradable nanofiber nonwovens for controlled release of proteins. J. Control. Release 2008, 127, 180-187. [CrossRef] [PubMed] 